\title{
Johtamispuhetta ja kehittämisdiskursseja suomalaisissa johtamisinstituutioissa: lähtökohtia johtamisen kehittämisen tutkimiseen
}

Johtamisen kehittäminen on kiehtova tutkimusaihe monistakin syistä. Ensinnäkin johtamisen kehittäminen vaikuttaa osallistujien kompetensseihin, kuten johtamisja vuorovaikutustaitoihin (Day 2011, 38). Toiseksi se vaikuttaa yksilön uraan ja organisaation seuraajasuunnitteluun (McCallum \& O'Connel 2009, 154-156). Lisäksi aihe on nähty tärkeäksi sen takia, että johtamista pidetään ratkaisuna monenlaisiin ongelmiin, liittyivätpä ne organisaatioon, siellä työskenteleviin ihmisiin tai yhteiskuntaan (Perruci \& Warty Hall 2018, 1-3). Tosiasiassa kukaan ei tiedä, millainen rooli johtamisella on erilaisten ongelmien ratkaisemisessa. Yleisesti omaksutut käsitykset johtamisen suuresta roolista saattavat pitää paikkaansa, mutta yhtä lailla voidaan väittää johtamisen roolin olevan illuusio, jolla ei ole todellisuuspohjaa. Tästä huolimatta on tärkeää tutkia johtamisen kehittämistä, sillä johtaminen myös määrittyy sen mukaisesti, miten sitä kehitetään. Lisäksi johtamisen kehittäminen on samalla organisaation sosiaalisen pääoman kehittämistä (Olivares ym. 2007, 77-79).

Johtamisesta ei ole olemassa yhtä yhtenevää näkökulmaa. Päinvastoin lähes jokainen johtamista määritellyt henkilö on tehnyt sen omalla tavallaan (Bass 1990, 11). Johtamista on määritelty ainakin 1500 eri tavalla, ja siitä on esitetty useita kymmeniä erilaisia malleja (Kellerman 2012). Johtamiskäsitysten suuren kirjon vuoksi on epäselvää, millaisilla menetelmillä johtamista kehitetään ja perustuvatko kehittämispyrkimykset tuoreimpaan tietoon (Day \& Harrison 2007). Johtamisen kehittämisen voidaan olettaa teoriassa lisäävän kohteena olevan organisaation kilpailukykyä, jos siinä hyödynnetään viimeaikaisia johtamisnäkemyksiä (Kark 2011, 507). Viimeaikaisessa tutkimuksessa johtajuus nähdään yhteisön vuorovaikutuksessa 
muodostuvana, kontekstuaalisena ja diskursiivisena ilmiönä, kun taas perinteinen johtamisnäkemys nojaa ajatukseen johtajasta valtaa pitävänä sankarina. Mikäli johtamista kehitetään kontekstuaalisten ja diskursiivisten johtamisnäkemysten avulla, voidaan siis saada aikaan parempia tuloksia kuin käytettäessä jotakin perinteistä, esimerkiksi sankarijohtamiseen liittyvää, johtamisnäkökulmaa. Lisäksi johtamisen kehittäminen on todennäköisesti vaikuttavampaa, jos käytetään kyseiseen organisaatioon räätälöityä johtamisnäkökulmaa.

Aihe on kiehtova siksikin, että tarkkaa tietoa johtamisen kehittämisessä käytetyistä menetelmistä ei ole saatavilla. Perinteisesti toiminta on kohdistunut yksittäiseen osallistujaan, johtajaan tai esihenkilöön (Mumford ym. 2000, 156). Uudempi johtamisen kehittäminen puolestaan keskittyy yhteisön vuorovaikutussuhteisiin ja sosiaaliseen pääomaan (Day 2011, 38). Epäselvää onkin, pyrkivätkö esimerkiksi johtamiskoulutuslaitokset kehittämään yksittäisiä esimiehiä vai työyhteisön sosiaalista pääomaa ja soveltuvatko käytetyt menetelmät parhaalla mahdollisella tavalla nykyiseen organisaatiomaailmaan (Ghoshal 2005, 76). Mikäli käytetään perinteisiä, luokkamuotoisia menetelmiä, on vaarana, ettei annetulla opetuksella ole juuri vaikutusta osallistujiin tai heidän edustamiinsa organisaatioihin.

\section{Johtamiskoulutusinstituutiot tutkimuksen kohteena}

Johtamisen kehittämistä voidaan tarkastella karkeasti ottaen joko tarjonta- tai kysyntänäkökulmasta. Tarjontanäkökulmalla tarkoitetaan kehittäjien näkökulmaa, kysyntänäkökulmalla taas johtamisen kehittämistä hankkivien yksilöiden ja organisaatioiden näkökulmaa. Väitöskirjatutkimuksessani (Juuti 2021) tarkastelin aihetta tarjontanäkökulmasta, jolloin tutkimuksen kohteena olivat johtamiskoulutusta tarjoavat instituutit. Tutkimukseni tarkoituksena oli selvittää, millaisia johtamispuheita ja johtamisen kehittämisdiskursseja maamme johtamiskoulutusinstituuteissa käytetään. Lisäksi selvitin, millaisia tulevaisuuden visioita instituuteilla on johtamisesta ja sen kehittämisestä.

Internetistä kerättyjen tietojen mukaan vuonna 2018 massamme oli 37 suurehkoa johtamiskoulutuslaitosta. Näistä 25 osallistui tutkimukseeni: 8 yliopiston jatko- ja täydennyskoulutuslaitosta ja 17 muuta koulutusinstituuttia. 
Jaoin koulutusinstituutit kehittämisen kohteena olevan kohderyhmän erilaisuuden vuoksi EMBA-kursseja järjestäviin ja sellaisiin, jotka eivät järjestä EMBA-kursseja. EMBA-kurssit eli Executive Master Business Administration -kurssit ovat ylimmälle johdolle tai ylimpään johtoon pyrkiville suunnattuja pitkäkestoisia täydennyskoulutusohjelmia. EMBA-kursseja järjesti seitsemän yliopiston jatko- ja täydennyskoulutuskeskusta. EMBA-kurssien kohderyhmänä on pääosin korkeimpaan johtoon kuuluvia tai sinne pyrkivä henkilöitä, kun taas muiden koulutuskeskusten kohderyhmänä ovat pääosin lähijohtajat ja keskijohto.

Tutkimukseen osallistui yhteensä 27 johtamiskoulutusinstituuttien johtajaa sekä koulutusta järjestävää asiantuntijaa. Haastatteluaineiston lisäksi käytin tutkimuksen aineistona internetistä keräämiäni ja haastateltavien antamia dokumenttiaineistoja. Analysoin aineistot sisällönanalyysin ja erityisesti niin sanotun Gioia-menetelmän avulla (Gioia ym. 2012).

\section{Perinteisestä johtamisnäkemyksestä kontekstuaaliseen johtamisen kehittämiseen}

Maamme ensimmäiset johtamiskoulutuslaitokset perustettiin sodan aikana ja välittömästi sen jälkeen (Rastor; JTO 1986). Johtamiskoulutus keskittyi aluksi teollisuuden työnjohtoon, mutta jo 1950-luvulle tultaessa koulutuksen piiriin tulivat myös keskijohdon ja palvelualojen edustajat. Työmarkkinajärjestöillä oli suuri rooli ensimmäisten johtamiskoulutuslaitosten perustamisessa. Sittemmin tuo rooli on hiipunut.

1970- ja 1980-luvuilla monet yksittäiset henkilöt tai ryhmät perustivat johtamiskoulutuslaitoksia, koska suomalaisen johtamisen laatua haluttiin parantaa. 1990luvun puolivälin jälkeen syntyi joitakin johtamiskoulutuslaitoksia johtamisen erikoisammattitutkinnon siivittämänä. EMBA-koulutus alkoi maassamme suhteellisen myöhään eli 1980- ja 1990-luvuilla, jolloin useimmat yliopistot alkoivat järjestää EMBA-kursseja jatko- ja täydennyskoulutuskeskuksissaan. Tätä ennen jotkut ulkomaiset koulutusinstituutit olivat tuoneet EMBA-kurssejaan Suomeen.

Väitöskirjatutkimukseni mukaan osa johtamiskoulutuslaitoksista käyttää edelleen varsin perinteisiä, sankarijohtamiseen liittyviä johtamisnäkemyksiä. Suurin osa instituuteista käyttää nykyaikaisempia, vuorovaikutteisia (esimerkiksi LMX-teorian mukaisia, ks. Häkkinen 2012) johtamisnäkemyksiä. Tällöin vuorovaikutus jäsentyy 
kuitenkin cartesiolaisen tradition ja olemuksellisen näkökulman mukaisesti yksilöiden väliseksi toiminnaksi, eikä suhteistetun näkökulman kontekstuaalista, aina erilaisena kehkeytyvää luonnetta tunnisteta. Monet johtamiskoulutuslaitosten edustajat puhuvat kontekstuaalisesta ja diskursiivisesta johtamisesta (Hoskins 2013), mutta vain muutama laitos käyttää niitä koulutuksessaan. Tällöinkin kontekstuaalisella johtamisella tarkoitetaan useimmiten coachingia, jossa keskustellaan osallistujan työhön liittyvistä asioista, kuten tapahtumista työpaikalla ja työn päämääristä.

Havaitsin tutkimuksessani myös, että useimmat johtamiskoulutuslaitokset käyttävät edelleen luokkahuoneopetusta. Osa laitoksista perustaa opetuksensa tietoisesti osallistujien kokemuksiin, mutta kokemuksia käsitellään varsin yleisellä tasolla, eikä niitä kytketä osaksi työskentelyprosessia. Varsinaisia kontekstuaalisia oppimisnäkemyksiä ei siis käytetä. Yksikään johtamiskoulutuslaitos ei ole siirtänyt johtamisen kehittämistä työpaikalle työn ohessa tapahtuvaksi toiminnaksi tavalla, jota esimerkiksi kontekstuaalisuutta ja tilannepohjaisuutta korostavassa situated learning -näkökulmassa ehdotetaan (Wenger-Trayner \& Wenger-Trayner 2015).

Tutkimukseni tulokset osoittavat myös, että instituutit, joiden koulutus perustuu perinteiseen johtamisdiskurssiin, käyttävät muita todennäköisemmin perinteisiä luokkamuotoisia koulutusmenetelmiä. Vastaavasti kontekstuaalisen johtamisnäkemyksen omaksuneet laitokset ovat omaksuneet muita todennäköisemmin myös uudenaikaisemmat menetelmät.

Haastatellut johtajat ja asiantuntijat sanovat käyttävänsä koulutuksessa samaa johtamisnäkemystä, jonka heidän asiakasorganisaationsa on omaksunut. Näin ollen koulutuslaitosten täytyy olla toiminnassaan joustavia ja omaksua useiden johtamispuheiden sisältämiä diskursseja. Lisäksi tämä merkitsee sitä, että instituutit eivät vie teoreettista johtamisdiskurssia eteenpäin vaan keskittyvät pääasiassa asiakasorganisaationsa miellyttämiseen. Yksi haastateltu henkilö myönsi, että hänen edustamansa koulutuslaitos pyrkii vain hankkimaan rahaa omalle organisaatiolleen. Jotkut koulutusorganisaatiot pyrkivät kuitenkin tuottamaan johtamiskoulutuksen avulla yleisempää, yhteiskunnallista hyötyä.

Verrattaessa EMBA-kursseja tarjoavien ja muiden koulutuslaitosten omaksumia johtamisdiskursseja voidaan todeta, että EMBA-kursseja tarjoavien laitosten koulutukseen sisältyy useammin asioiden johtamiseen (management) liittyviä aiheita, kuten strategiaa, taloutta ja markkinointia. Ylimmän johdon koulutuksessa ihmisten 
johtamiseen (leadership) liittyvillä aiheilla onkin vain pieni rooli. Sen sijaan keskijohdon ja lähijohtajien koulutuksessa ihmisten johtaminen on pääosassa.

Haastatellut henkilöt puhuivat johtamiseen ja johtamisen kehittämiseen liittyvistä tulevaisuuden näkymistä paljon vähemmän kuin niiden nykytilasta. Tämä voidaan tulkita joko niin, ettei johtamiskoulutuslaitoksilla ole selkeitä tulevaisuuden visioita, tai niin, että instituuttien edustajat pelkäävät paljastaa niitä. Laitokset aikovat toteuttaa johtamiskoulutusta tulevaisuudessa samaan tapaan ja samanlaisia johtamisdiskursseja soveltaen kuin nykyisinkin. Ainoa muutos on, että uutta tekniikkaa aiotaan soveltaa nykyistä enemmän tai kehittää koulutusta humaanimpaan suuntaan tai toteuttaa nämä molemmat muutokset yhtä aikaa. Tosin eräät haastateltavat totesivat, että he ovat jo kokeilleet uuden tekniikan soveltamista johtamiskoulutuksessa mutta ovat huomanneet, että osallistujat eivät pidä virtuaalisesta koulutuksesta vaan haluavat tavata toisiaan kasvokkain.

\section{Teorian ja käytännön vuoropuhelu johtamisen kehittämisen ytimeen}

Väitöstutkimukseni tulokset viittaavat siihen, että johtamista ei kehitetä viimeaikaisten johtamisnäkökulmien ja kehittämisen menetelmien mukaisesti. Päinvastoin näyttää siltä, että useimmat johtamiskoulutuslaitokset käyttävät perinteisiä menetelmiä ja perinteisiä näkökulmia. Johtamista ei voi oppia luokassa, eivätkä sankarijohtamisen mallit toimi enää nykyisin. Lisäksi näyttää siltä, etteivät koulutuslaitokset aio juuri muuttaa toimintatapaansa tulevaisuudessa.

Tutkimukseni pohjalta voidaan suositella, että johtamiskoulutuslaitokset solmisivat entistä tiiviimmät yhteydet johtamisen tutkimusta tekeviin yliopistoihin. Näin olisi todennäköisempää, että koulutuksessa käytettäisiin viimeaikaisia johtamisnäkemyksiä. Lisäksi organisaatioiden johtamiskäytännöt saataisiin nopeammin tutkijoiden tarkasteltavaksi. Näin toimien voitaisiin olettaa kuilun johtamisen teorian ja käytännön välillä pienenevän. Lisäksi laitosten tarjoama koulutus kohdistuisi todennäköisesti sellaisten johtamisnäkemysten kehittämiseen, jotka soveltuvat parhaiten kuhunkin organisaatioon.

Toiseksi voidaan suositella, että johtamisen kehittämisen menetelmiä uudistettaisiin niin, että ne entistä paremmin ottaisivat huomioon sen kontekstin, jossa 
johtaminen tapahtuu. Johtamista ei voida oppia, mikäli johtaminen irrotetaan siitä sosiaalisesta yhteydestä, jossa se tapahtuu. Johtamisen kehittämistä toteutettaisiin parhaiten työpaikoilla työskentelyn lomassa.

Johtamisen kehittäminen on tärkeä ja ajankohtainen aihe, ja sen kunnollinen toteuttaminen edellyttää koulutusinstituuttien ja johtamisen tutkijoiden entistä tiiviimpää yhteistyötä. Vain näin voidaan taata, että johtamisen kehittämisessä hyödynnetään uusinta tietämystä.

Sini Juutin johtamisen väitöskirja Current and future leadership education in Finland tarkastettiin Jyväskylän yliopistossa 26.3.2021. Väitöskirja löytyy sähköisessä muodossa osoitteesta http://urn.fi/URN:ISBN:978-951-39-8519-6

\section{Kirjoittaja}

\section{Sini Juuti}

KTT, DI, projekti-insinööri

sähköposti: sini.juuti@aalto.fi

twitter: @Juutisini

\section{Kirjallisuus}

Bass, B. (1990) Bass \& Stogdill's handbook of leadership: Theory, research \& managerial applications. Third edition. New York: The Free Press.

Day, D. (2011) Leadership development. Teoksessa A. Bryman, D. Collinson, K. Grint, B. Jackson \& M. Uhl-Bien (toim.) The Sage handbook of leadership. Los Angeles: Sage, 37-50.

Day, D. \& Harrison, M. (2007) A multilevel, identity-based approach to leadership development. Human Resource Management Review 17 (4), 360-373. https://doi.org/10.1016/j.hrmr.2007.08.007

Ghoshal, S. (2005) Bad management theories are destroying good management practices. Academy of Management Learning \& Education 4 (1), 75-91. https://doi.org/10.5465/amle.2005.16132558 
Gioia, D., Corley, K. \& Hamilton. A. (2012) Seeking qualitative rigor in inductive research: Notes on the Gioia methodology. Organizational Research Methods 16 (1), 15-31. https://doi.org/10.1177\%2F1094428112452151

Hosking, D.-M. 2013. Constructing power: Entitative and relational approaches. Teoksessa D.-M. Hosking, P. Dachler \& K. Gergen, K. (toim.) Management and organizations: Relational alternatives to individualism. Charging Falls: Taos Institute Publications, 51-71.

Häkkinen, S. (2012). Towards trust-based model of leadership within the leadermember exchange theory framework: A qualitative study of leaders' trustworthiness in the SME context. Dissertation. Joensuu: University of Eastern Finland.

JTO (2006) Yritysten asialla: Johtamistaidon opisto JTO 1946-2006.

Juuti, S. (2021) Current and future leadership education in Finland. JYU Dissertations 351. Jyväskylä: Jyväskylän yliopisto. http://urn.fi/URN:ISBN:978-951-39-8519-6

Kark, R. (2011) Games managers play: Play as a form of leadership development: Academy of Management Learning \& Education 10 (3), 507-527. https://doi.org/10.5465/AMLE.2010.0048

Kellerman, B. (2012) Cut off the pass: The limits of leadership in the 21st century. Governance Studies of Brooking Institution. https://www.brookings.edu/ wp-content/uploads/2016/06/0810_leadership_deficit_kellerman.pdf (luettu 2.3.2020)

McCallum, S. \& O'Connell, D. 2009. Social capital and leadership development: Building stronger leadership through relational skills. Leadership \& Organizational development Journal 30 (2), 152-166. https://doi.org/10.1108/01437730910935756

Mumford, M. \& Zaccaro, S. \& Connelly, M. \& Marks, M. (2000) Leadership skills: Conclusions and future directions. Leadership Quarterly 11 (1), 155-170. https://doi.org/10.1016/S1048-9843(99)00047-8

Olivares, O., Peterson, G. \& Hess, K. (2007) An existential-phenomenological framework for understanding leadership development experiences. Leadership \& Organization Development Journal 28 (1), 76-91. https://doi.org/10.1108/01437730710718254 
Perruci, G. \& Warty Hall, S. (2018) Introduction. Teoksessa G. Perruci \& S. Warty Hall (toim.) Teaching leadership: Bridging theory and practice. Cheltenham: Edward Elgar, 1-8.

Rastor. Wikipedia. https://fi.wikipedia.org/wiki/Rastor (luettu 12.6.2018)

Wenger-Trayner, E. \& Wenger-Trayner, B. (2015) Learning in a landscape of practice: A framework. Teoksessa E. Wenger-Trayner, M. Fenton-O'Creevt, C. Hutcinson, C. Kubiak \& B, Wenger-Trayner (toim.) Learning in landscape of practice: Boundaries, identity, knowledgeability in practice-based learning. Lontoo: Routledge, 13-29. 